\title{
Discussion on Measuring Method of Phytase Activity According to Term Enzyme Specificity
}

ISSN: 2576-8840

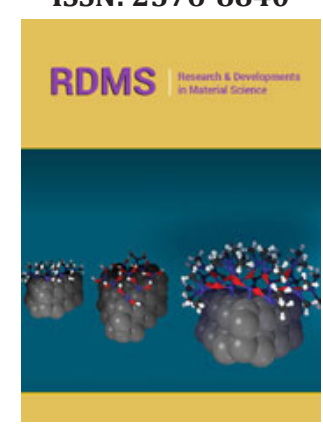

*Corresponding author: Gan Zhao, Department of Biochemistry and Molecular Biology, College of Life Sciences, South China Agricultural University, China

Submission: 侮 May 08, 2020

Published: 眥May 14, 2020

Volume 13 - Issue 3

How to cite this article: Gan Zhao. Discussion on Measuring Method of Phytase Activity According to Term Enzyme Specificity. Res Dev Material Sci. 13(3). RDMS.000814. 2020. DOI: $10.31031 /$ RDMS.2020.13.000814

Copyright@Gan Zhao, This article is distributed under the terms of the Creative Commons Attribution 4.0 International License, which permits unrestricted use and redistribution provided that the original author and source are credited.

\section{Gan Zhao*}

Department of Biochemistry and Molecular Biology, South China Agricultural University, China

\section{Introduction}

According to the term enzyme specificity, a discussion on measuring method of phytase activity used now showed that the method could not show the order of inorganic phosphates released from sodium phytate to be helpful to classify or group the phytases studied now, but it is still be useful in production units at the grassroots level and preliminary researches of the phytase. The term enzyme specificity could be useful to interpreting accurately the results got by measuring enzyme activity and to judging the advantages and disadvantages of the method to measure enzyme activity. The discussion on the term enzyme specificity here could also be used as an example for students to study and apply the term they met or will meet.

Enzyme has been deeply concerned and studied as an important class of biocatalyst and the term enzyme specificity is one of the basic concepts introduced in text books $[1,2]$. The accurate implication and expression of the term enzyme specificity was discussed, for the different understanding existed in different textbooks [3]. For example, in pentose phosphate pathway, sedoheptulose 7-phosphate and glyceraldehyde 3-phosphatecan not only react to become xylulose 5 -phosphate and ribose5-phosphatecatalyzed by transketolase, but can also react to become erythrose 4-phosphate and fructose 6-phosphatecatalyzed by transaldolase $[1,2]$. Though sedoheptulose 7-phosphate and glyceraldehyde 3-phosphateare all the same substrates for transketonase and transaldolase, the reactions and the products catalyzed by the both enzymes are not the same respectively. So reacting specifically and producing the specific product(s) should be considered fundamentally and importantly when the term enzyme specificity is used to analyze an enzymatic reaction [3].

Phytaseis the important enzyme used in food and feed industries [4], in remediation of polluted soils [5], in the improvement of plant growth and nutrition [6]. The Nomenclature Committee of the International Union of Biochemistry and Molecular Biology (NC-IUBMB) classifies phytases as either 3-phytase (EC 3.1.3.8), 6-phytase (EC 3.1.3.26) or 5-phytase (EC 3.1.3.72) depending upon the specific position of the initial dephosphorylation reaction [7]. Measuring phytase activity is the basic experiment during the researches. The method, having been used typically to measure phytase activity, has been based on measuring the released inorganic phosphates catalyzed by the phytase by a modification of the ammonium molybdate method [8]. To put it simply, phytase reaction mixture included some sodium phytate, acetate buffer or glycine-HCl buffer or citric acid-sodium citrate buffer of a certain concentration and with a certain $\mathrm{pH}$ and the crude enzyme solution of a certain concentration, and after its work at some tempeture for a period, the phytase activity was determinated by measuring the resulted inorganic phosphate with the ammonium molybdate solution $[9,10]$. But the method could not show the order of inorganic phosphates released from sodium phytate. For example, Greiner et al. [11] showed that the phytate-degrading enzyme P2 of E. coli dephosphorylates myoinositol hexakisphosphate in a stereospecific way by sequential removal of phosphate groups 
via D-Ins $(1,2,3,4,5) \mathrm{P}_{5}, \mathrm{D}-\operatorname{Ins}(2,3,4,5) \mathrm{P}_{4}, \mathrm{D}-\operatorname{Ins}(2,4,5) \mathrm{P}_{3}, \operatorname{Ins}(2,5) \mathrm{P}_{2}$ to finally Ins(2)P (notation 6:1:3:4:5), using a combination of highperformance ion chromatography analysis and kinetic studies. Greiner et al. [12] showed that the phytate-degrading enzyme from baker's yeast dephosphorylates myo-inositol hexakisphosphate in a stereospecific way by sequential removal of phosphate groups via $\mathrm{D}-\operatorname{Ins}(1,2,4,5,6) \mathrm{P}_{5}, \mathrm{D}-\operatorname{Ins}(1,2,5,6) \mathrm{P}_{4}, \mathrm{D}-\operatorname{Ins}(1,2,6) \mathrm{P}_{3}, \mathrm{D}-\operatorname{Ins}(1,2)$ $\mathrm{P}_{2}$, to finally Ins(2)P (notation 3/4/5/6/1), using a combination of high-performance ion chromatography analysis and kinetic studies. What do the facts mean? It shows that the reaction progresses catalyzed by the two phytate-degrading enzymes and the resulted intermediate products which exist stably and can be determinated are not the same respectively although the both enzymes act on the same substrate sodium phytate and the produced end products such as Ins(2)P and inorganic phosphates are the same. So, strictly speaking, the two enzymes are not the same according to the term enzyme specificity. It is obvious that only measuring phytase activity cannot provide more information to study phytase further. Maybe this analysis can be useful to realize why the phytases can be classified as either 3-phytase (EC 3.1.3.8), 6-phytase (EC 3.1.3.26) or 5-phytase (EC 3.1.3.72). And maybe this analysis can also be useful to realize no matter whether the phytases can be grouped as histidine acid phytase (HAPhy), bpropellerphytase (BPPhy), purple acid phytase (PAPhy), or protein tyrosine phytase, as reviewed by Handa et al. [4], measuring phytase activity is only the most basic work. Considering the progresses and intermediate products in the phytate-catalyzing reaction, maybe it is better that phytases are a class of phosphatases which catalyse phosphate monoester hydrolysis of phytic acid in a stepwise manner, there by generating less phosphorylated myo-inositol derivatives and inorganic phosphate [13]. But it should be awared that the method used to measure phytase activity mentioned above has the advantages of low price and convenient use in production units at the grassroots level and preliminary researches of the phytase, for it grasps the generated inorganic phosphate in the reaction system no matter what less phosphorylated myo-inositol derivatives are generated.

As shown above, the term enzyme specificity could be useful to interpreting accurately the results got by measuring enzyme activity and to judging the advantages and disadvantages of the method to measure enzyme activity. The discussion on the term enzyme specificity here could also be used as an example for students to study and apply the terms they met or will meet.

\section{References}

1. Nelson DL, Cox MM (2005) Lehninger principles of biochemistry. $\left(4^{\text {th }}\right.$ edn), WH Freeman and Company, New York, USA.

2. Garret RH, Grisham CM (2007) Biochemistry. ( $3^{\text {rd }}$ edn), Thomson Learning Academic Resource Center.

3. Zhao G (2019) Discussion on the concept of enzyme specificity. Shandong Chemical Industry 48: 114.

4. Handa V, Sharma D, Kaur A, Arya SK (2020) Biotechnological applications of microbial phytase and phytic acid in food and feed industries. Biocatalysis and Agricultural Biotechnology 25(101600): 1-13.

5. Gianfreda L, Rao MA (2004) Potential of extra cellular enzymes in remediation of polluted soils: A review. Enzyme and Microbial Technology 35: 339-354.

6. Singh B, Boukhris I, Pragya KV, Yadav AN (2020) Contribution of microbial phytases to the improvement of plant growth andnutrition: A review. Pedosphere 30(3): 295-313.

7. Berry D, Shang FC, Zelazny LW (2009) Measurement of phytase activity in soil using a chromo phoric tethered phytic acid probe. Soil Biology and Biochemistry 41: 192-200.

8. Heinonen JK, Lahti RJ (1981) A new and convenient colorimetric determination of inorganic ortho phosphate and its application to the assay of inorganic phosphatase. Anal Biochem 113: 313-317.

9. Bhavsar K, Buddhiwant P, Soni SK, Sarkar DDS, Khire JM (2013) Phytaseisozymes from aspergillusniger NCIM 563 under solid state fermentation: Biochemical characterization and their correlation with submerged phytases. Process Biochemistry 48: 1618-1625.

10. Yu HL (2019) Critical control points for the determination of feed phytase activity. Feed Review (8): 38-40.

11. Greiner R, Carlsson NG, Alminger ML (2000) Stereospecificity of myoinositol hexakis phosphatedephosphorylation by a phytate-degrading enzyme of Escherichia coli. Journal of Biotechnology 84: 53-62.

12. Greiner R, Alminger ML, Carlsson NG (2001) Stereospecificity of myoInositol hexakisphosphate dephosphorylation by a phytate-degrading enzyme of baker's yeast. J Agric Food Chem 49: 2228-2233.

13. Boyce A, Walsh G (2007) Purification and characterisation of an acid phosphatase with phytase activity from mucorhiemalis wehmer. Journal of Biotechnology 132: 82-87. 